\title{
India's Road to Independence in Manufacturing Active Pharmaceutical Ingredients: Focus on Essential Medicines
}

\author{
Jerin Jose Cherian ${ }^{1}\left(\right.$, Manju Rahi ${ }^{2, *}\left(\mathbb{D}\right.$, Shubhra Singh ${ }^{3}$, Sanapareddy Eswara Reddy ${ }^{4}$, Yogendra Kumar Gupta ${ }^{5}$, \\ Vishwa Mohan Katoch ${ }^{6}$, Vijay Kumar ${ }^{1}$, Sakthivel Selvaraj ${ }^{7}$, Payal Das ${ }^{2} \mathbb{D}$, Raman Raghunathrao Gangakhedkar ${ }^{2}$, \\ Amit Kumar Dinda ${ }^{8}{ }^{\circ}$, Swarup Sarkar ${ }^{9}$, Puroshottambhai Devshibhai Vaghela ${ }^{10}$ and Balram Bhargava ${ }^{6}$
}

check for updates

Citation: Cherian, Jerin Jose,

Manju Rahi, Navdeep Rinwa

Shubhra Singh, Sanapareddy Eswara Reddy, Yogendra Kumar Gupta,

Vishwa Mohan Katoch, Vijay Kumar, Sakthivel Selvaraj, Payal Das, et al.

2021. India's Road to Independence

in Manufacturing Active

Pharmaceutical Ingredients: Focus on Essential Medicines. Economies 9: 71. https://doi.org/10.3390/

economies 9020071

Academic Editor: Ralf Fendel

Received: 18 January 2021

Accepted: 8 March 2021

Published: 3 May 2021

Publisher's Note: MDPI stays neutral with regard to jurisdictional claims in published maps and institutional affiliations.

Copyright: (c) 2021 by the authors. Licensee MDPI, Basel, Switzerland. This article is an open access article distributed under the terms and conditions of the Creative Commons Attribution (CC BY) license (https:// creativecommons.org/licenses/by/ $4.0 /)$.
1 Division of Basic Medical Sciences, Indian Council of Medical Research, New Delhi 110029, India; jerin.cherian.dhr@gmail.com (J.J.C.); drvijayprabhakar@gmail.com (V.K.)

2 Division of Epidemiology \& Communicable Diseases, Indian Council of Medical Research, New Delhi 110029, India; daspayal006@gmail.com (P.D.); rrg7@rediffmail.com (R.R.G.)

3 National Pharmaceutical Pricing Authority, New Delhi 110001, India; chairman.nppa@nic.in

4 Central Drugs Standard Control Organization, New Delhi 110002, India; se.reddy@nic.in

5 Standing National Committee on Medicines, Department of Health Research, Ministry of Health and Family Welfare, New Delhi 110001, India; ykykgupta@gmail.com

6 Department of Health Research (ICMR), Ministry of Health and Family Welfare, New Delhi 110001, India; vishwamohankatoch18@gmail.com (V.M.K.); balrambhargava@yahoo.com (B.B.)

7 Health Economics, Financing and Policy, Public Health Foundation of India, New Delhi 110017, India; shakti@phfi.org

8 Department of Pathology, All India Institute of Medical Sciences, New Delhi 110029, India; dindaaiims@gmail.com

9 Translational Global Health Policy Research Cell, CG Pandit Chair (Medical), Indian Council of Medical Research, New Delhi 110029, India; sarkar.swarup@gmail.com

10 Department of Pharmaceuticals, Ministry of Chemicals \& Fertilizers, New Delhi 110001, India; cp@trai.gov.in

* Correspondence: drmanjurahi@gmail.com

Abstract: Background: Active Pharmaceutical Ingredient (API) manufacturing is an important segment of the Indian pharma industry. India ranks third in terms of volume of medicines produced, and is a major global supplier of generic medicines. However, India depends heavily on the import of several raw materials used to produce some of these medicines. Main Body: This paper highlights how the situation emerged, as well as the various steps taken by the government to reduce import dependency and promote domestic manufacturing of APIs. Through various consultations with government officials, policy analysts and academicians, and interactions with key industry experts, the paper also highlights the public health perspectives of such dependence, especially regarding the secure access to essential medicines. India needs a conducive ecosystem to capitalize on the full potential of its API manufacturing capabilities, which may require some short-term and some mid/long-term interventions. Conclusions: It concludes by providing certain short-, medium- and long-term recommendations in the policy, fiscal and technology domains, to promote API independence. It also summarizes the various steps taken by the government in moving towards domestic manufacturing of APIs.

Keywords: active pharmaceutical industry; domestic manufacturing; essential medicines; import dependence; India; pharmaceutical policy; public health

\section{Introduction}

India has today emerged as the "Pharmacy of the Global South", with its pharmaceutical industry ranking third largest in the world in terms of medicines produced by volume. India accounts for $20 \%$ of global generic medicine exports by volume and supplies over $50 \%$ of global demand for vaccines (Indian Pharmaceutical Alliance 2019). Despite all of these achievements, the Indian pharmaceutical industry has, over the years, become 
significantly dependent on import of the basic raw materials that are used to produce the Finished Dosage Formulations.

China is the world's main supplier of raw materials for Active Pharmaceutical Ingredients (APIs), Key Starting Materials (KSM) and intermediates (Knowledge Partnership Programme 2015). While India is also a major producer of API, accounting for around $20 \%$ of global production by volume and 7\% by value (Market Wrap ICICI 2019), it is dependent on imports for around 32\% of its requirement (Assocham India Indian API Market Outlook 2022 2019), for which China is the major supplier (Figure 1). In 2018, 67.56\% (by value) of raw materials needed to produce formulations by Indian companies were imported from China, according to a statement in Parliament by the Minister of Chemicals and Fertilizers (Gowda SS 2020a). In terms of volume, China's share of imports stands at around $60 \%$ (Minister of Commerce and Industry, Department of Commerce, Government of India 2019).

\section{(a) API production by value}

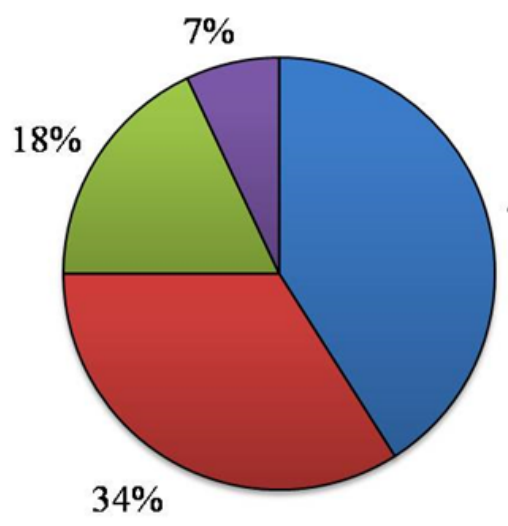

$41 \%$

口USA

$\square$ Other countries

$\square$ China

$\square$ India

\section{(b) API production by volume}

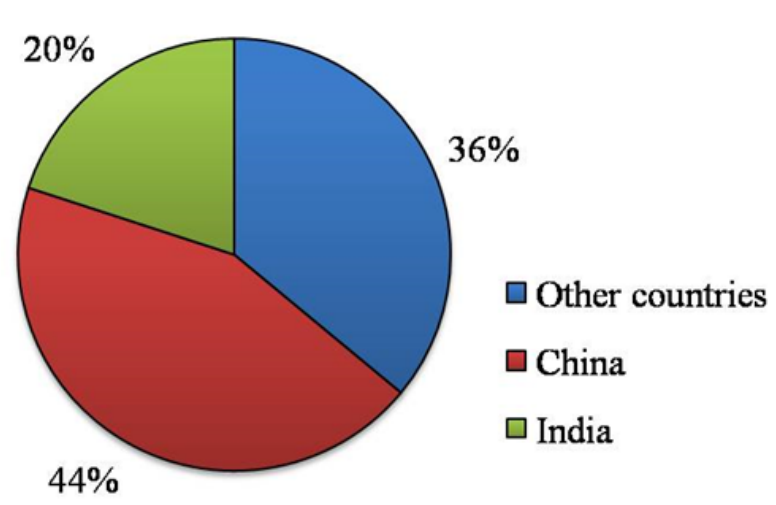

Figure 1. Global production of Active Pharmaceutical Ingredients (API): The graph represents the API production globally for USA, China, India and other countries, in terms of (a) value and (b) volume (source: Market Wrap ICICI 2019).

This import dependence of API and intermediates is particularly high for many of the low-value, high-volume and off-patent essential medicines that are used widely by the Indian population (Figure 2). India also has sizeable export of generic medicines that are indirectly dependent on China for their raw material. The Indian Council of Medical Research (ICMR) took cognizance of the matter, especially regarding access to essential medicines from a public health point of view. It was thought to be important to prepare a situation analysis and identify the best steps towards India's self-sufficiency in API production. It was decided that the best way to do it was through extensively consulting all relevant stakeholders. The overall objective was to find ways to improve availability of essential medicines in India, with special emphasis on self-reliance. 


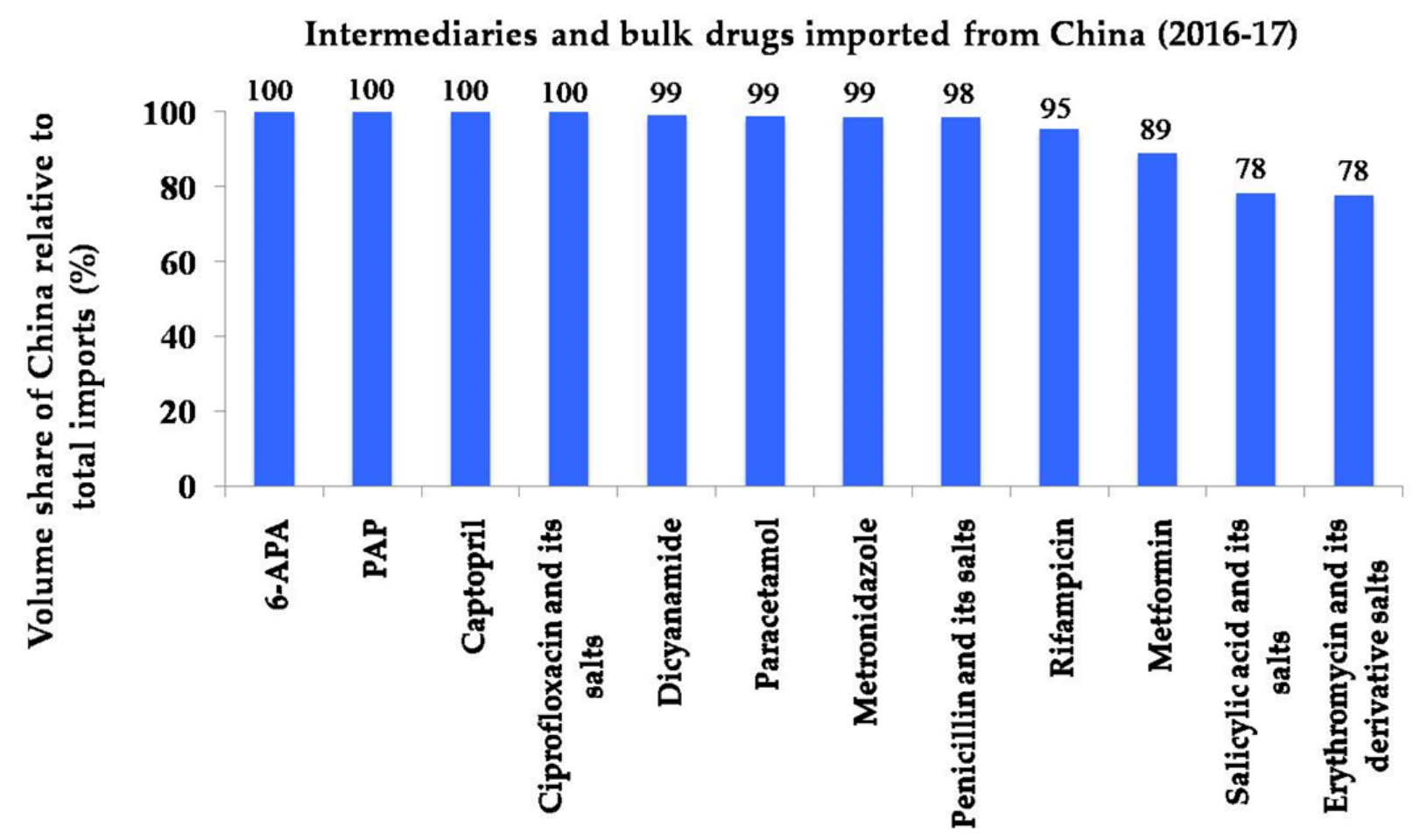

Figure 2. India's import basket from China: Chinese volume share of India's import basket for key intermediaries and bulk drugs for the year 2016/2017 (source: Confederation of Indian Industry 2017).

\section{Methodology}

A National Consultation meeting of ICMR with Pharmaceutical Industry was held on 17 July 2019, with participation from various stakeholders, including National Institution for Transforming India (NITI) Aayog, Department of Pharmaceuticals (DoP), Drug Controller General of India (DCGI), National Pharmaceutical Pricing Authority (NPPA), industry experts, policy analysts and academicians. The scope of the consultation was to help identify areas of collaboration in the pharma-academia space, to discuss the various roadblocks and to formulate recommendations or solutions to the identified problems. India's API dependence in the context of public health and essential medicines was identified as one of the thrust area. In the subsequent meetings, a methodology was formulated to understand the existing API dependence that has evolved over the past few years and to tabulate various efforts undertaken to mitigate this scenario.

Since the challenges of API dependence were multi-faceted, it was decided to focus on possible public health implications following shortage of essential medicines. To further elaborate this concept, a case study of shortage of Penicillin-G was suggested. The experts at the consultation meeting suggested this scoping review to be conducted, using three methods. This included the following:

- Desktop research - to identify published literature, reports or news articles, and to carefully study them to understand the evolution of India's heavy import dependence for pharmaceutical raw materials. Many reports would also include recommendations made by expert groups regarding the potential solutions to circumvent this dependence.

- Interview with key stakeholders-Various key stakeholders, including Department of Pharmaceuticals (DoP), Drug Controller General of India (DCGI), industry experts, civil society groups, policy analysts and academicians, were interviewed, to gather valuable domain specific inputs regarding the increasing import dependence of pharmaceutical raw materials. These insights helped consolidate all the previous recommendations and synthesize alternative strategies to address the problem. Fur- 
ther information required was collected through email exchanges, personal interviews and formal meetings. To better understand the different perspectives of various stakeholders, separate interactions were required with crucial pharma industry experts, academic experts in the industrial policy domain and key government officials from DoP and DCGI.

- Consultative meetings-There were two consultation meetings of the key stakeholders, to discuss the findings that were gathered and to further seek their opinion. On 3 March 2020, a consultation meeting was organized by ICMR, where all stakeholders deliberated on the information gathered. Besides this, the team drafting this scoping review had six consultative meetings, to have in-depth discussions on the contents of the report.

\section{Case Study of Pen-G: Death of Indian Fermentation Units through Predatory Competition}

Fermentation technology has long been used for the production of various medically significant products, such as antibiotics, solvents such as ethanol and intermediary compounds such as citric acid. Other fermentation products include therapeutic recombinant proteins and DNA, anti-viral drugs and monoclonal antibodies. Stiff competition has led the Indian bulk drug industry, which uses fermentation-based production to a stage of closure, making the country completely reliant on imports for key intermediates for many essential antibiotics, including semi-synthetic penicillin and cephalosporins. This led to total import dependence for medicines like Penicillin and Erythromycin (Dey and Singh 2009). What is even more worrying is the fact that this dependence has gradually extended to almost all fermentation-based APIs and intermediates. Many fermentation-based public and private manufacturing units across the country started facing difficulties in the 1990s, due to imports from China. Many of them were forced to close, giving way to heavy imports of raw materials for various pharmaceuticals, including some antibiotics, antifungals and anticancer medicines (Table 1).

Table 1. Some examples of the fate of fermentation-based API plants in India * (source: Export-Import Bank of India 2016).

\begin{tabular}{cccc}
\hline Name of Bulk Drug & Name of Producers & Production Commenced & Status \\
\hline Penicillin G/V & $\begin{array}{c}\text { Alembic, Sarabhai, Indian Drugs and } \\
\text { Pharmaceuticals Limited, JK Torrent, } \\
\text { Ranbaxy, Standard }\end{array}$ & Early 1960s & Production stopped \\
Streptomycin & $\begin{array}{c}\text { Alembic, Sarabhai, Indian Drugs and } \\
\text { Pharmaceuticals Limited }\end{array}$ & Early 1960s & Production stopped \\
Kanamycin & Alembic & Early 1970s & Production stopped \\
Vitamin B 12 & Alembic, Themis, Merck Sharp \& Dohme & Early 1970s & Closed \\
Tetracycline & Sarabhai, Indian Drugs and Pharmaceuticals & Early 1980s & Production stopped \\
Ascorbic Acid & Limited, Pfizer & Early 1980s & Closed \\
Erythromycin & Sarabhai, Jayant Vitamin & Early 1980s & Partial operation \\
Griseofulvin & Alembic, Themis, Indian Drugs and & Late 1980s & Closed \\
Gentamycin & Pharmaceuticals Limited, Standard & Glaxo & Late 1980s \\
Cephalosporin & Hindustan Antibiotics Limited, Themis & Alembic & Early 1990s \\
Cyclosporin & Biocon, Mylan & Late 1990s & Closed \\
Mitomycin 'C' & Themis & Early 1990s & Closed \\
\hline
\end{tabular}

* Adapted with permission from the author. 
Pen-G is a starting material for a majority of semi-synthetic penicillin and semisynthetic cephalosporins, while 6-APA is derived from Pen-G and is the " $n-1$ " intermediate for the manufacturing of two of the leading large volume, semi-synthetic penicillins, namely Amoxicillin and Ampicillin. India is currently highly dependent on imports for both Pen-G and 6-APA (Minister of Commerce and Industry, Department of Commerce, Government of India 2019).

India had significant domestic production of both Pen-G and 6-APA in the late 1990s and mid-2000s; however, the last decade and half has seen a steady decline in local production. Among the factors behind India's growing dependence on Pen-G imports were policies, both at home and abroad, together with technological and commercial challenges (Confederation of Indian Industry 2017). This case study illustrates the fact that domestic manufacturing of essential medicines has been an uphill task for India as huge investments are needed to achieve economies of scale and compete internationally.

Some of the reasons that led to India's API import dependence include the following:

- Indian pharmaceutical companies depend on imported APIs mainly for their low cost and not for any technological reason.

- Importing raw material saves $15-20 \%$ of the overall costs for the Indian drug makers (Assocham India Indian API Market Outlook 2022 2019).

- The Chinese Government subsidizes its industry, giving it a cost advantage over India. For example, China assures around 13\% tax incentives for the export of APIs (World Health Organization 2017a).

- The Chinese have an advantage in built-up capacities. They have huge capacities built up with the support of the government, and managed by the private industry.

- API manufacturing generally yields a slow profit margin; hence, the economies of scale are very vital for this industry.

- Indian manufacturers have steadily migrated up the value chain, prioritizing valueadded formulations that have higher margins.

- India, which used to be a world leader in fermentation technology, has had to shut down most of its facilities due to lack of profitability (Confederation of Indian Industry 2017).

Till the early 2000s, the Government of India controlled the production of Pen-G in the country through licenses (Ghosh 2019). These licenses were given to a limited set of players, and for limited production capacities. As a result, the total manufacturing capacity consistently remained below the country's overall demand, and the unit capacities at plant levels were sub-optimal to generate economies of scale. Meanwhile, China strategically promoted its own API industry, while India opened up its economy to global players, giving Indian businesses the freedom to either import, manufacture or locally procure the necessary raw materials based on economic viability.

Furthermore, some international manufacturers also often dumped their production in the Indian market at a price below the economic cost of production, making it difficult for Indian manufacturers to compete. This drove down prices of imports to a level where Indian companies found domestic manufacturing no longer profitable. As a result, both public- and private-sector manufacturers in India began shutting down production. Indian manufacturers (such as Hindustan Antibiotic Limited in the public sector and major private sector players) that were engaged in manufacturing Penicillin G were gradually outperformed (Down to Earth 2020).

During the 1990s, the production of 6-APA in India followed a pattern similar to that of Pen-G. Over the next decade, half of Indian domestic producers shut operations (Confederation of Indian Industry 2017). Relaxation of rules concerning imports of 6-APA combined with sub-scale capacities were responsible for the domestic production decline, similar to the Pen-G example. 
China's cost advantages in fermentation-based products are driven by a variety of factors, including low costs of raw material and utilities, provision of subsidies by the state and good economies of scale, due to large scale production (Figure 3). For example, Chinese manufacturers have managed to keep raw materials costs for Penicillin-G production lower by $3-4 \%$, due to significant improvements in strain yields, using the latest technologies. The abundance of and proximity to raw materials in the countryhave also helped lower costs of purchase and transport of raw materials, contributing to savings of almost 10 to 15\% (Minister of Commerce and Industry, Department of Commerce, Government of India 2019).

Chinese manufacturers also have the advantage of lower cost of utilities compared to their Indian counterparts, who pay twice the rate on a per KWH basis for electricity and over 40 to $50 \%$ more for steam (Minister of Commerce and Industry, Department of Commerce, Government of India 2019). Their massive scale of operations also confers competitive advantages to Chinese operations, who also get significant subsidies in terms of export rebates, equaling 10 to $15 \%$ of their revenues, at various times, from the government (Minister of Commerce and Industry, Department of Commerce, Government of India 2019). These advantages in the pharmaceutical-manufacturing sector have forced other countries to import the more cost-effective Chinese APIs.

\section{Some factors that are advantageous to Chinese Pharma manufacturers}

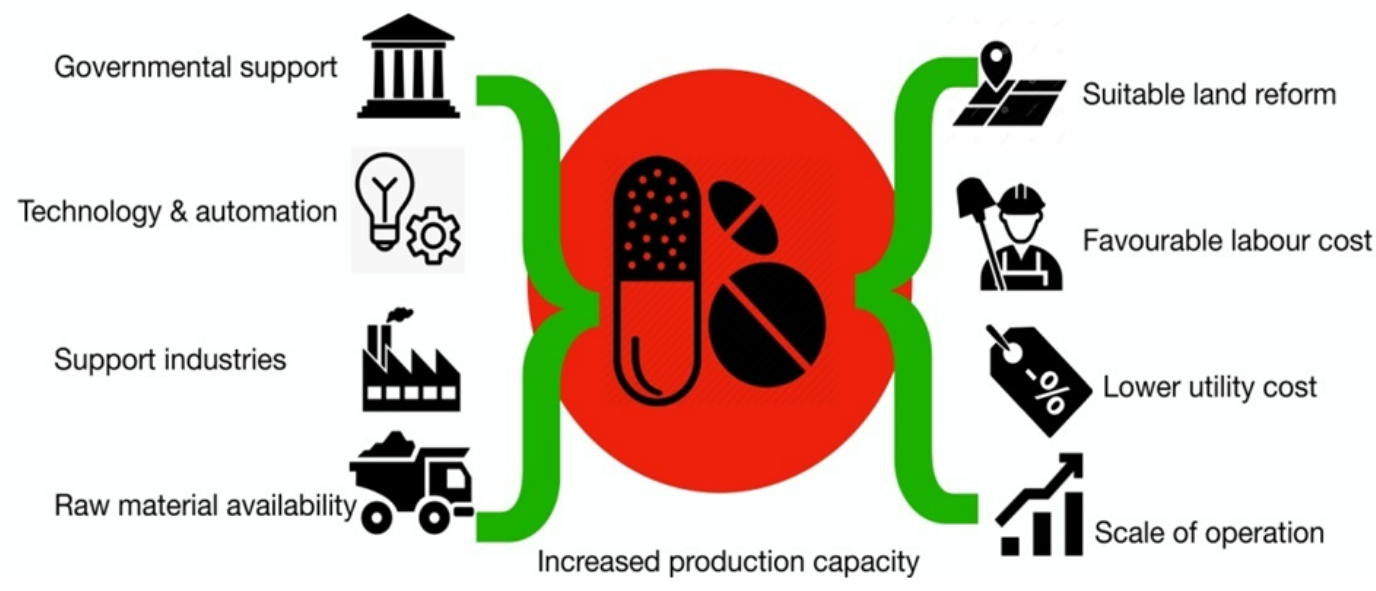

Figure 3. Factors providing advantage to Chinese bulk drug manufacturers.

\section{Public Health and Medicine Security: What Can Happen if Supply Chain Disruptions Occur}

Over the decades, India has taken big strides in improving the health status of the country's population. While the death rate per 1000 population in the country has reduced over the last four decades, from 14.9 in 1971 to 6.3 in 2017, the Infant Mortality Rate (IMR), widely accepted as a crude indicator of the overall health scenario of a country, has declined from 53 to 33 per 1000 live births in the same period (SRS Bulletin 2019). Since 2000, life expectancy at birth in India has risen from 62.5 years to 66 years in 2013 (World Health Organization-Global Health Observatory 2020). There have been other major public health successes too, with India declared polio free in March 2014, and free of maternal and neonatal tetanus in August 2015. However, for all of this progress, the country carries a disproportionate burden of the world's ill health, bearing $20 \%$ of the global disease burden (Global Burden of Disease Report 2017). 
India bears a high share of the world's incidence of infectious diseases. The country had 10 million cases of tuberculosis in 2018, accounting for $27 \%$ of the world total (World Health Organization-GTR 2019); it also has the world's largest number of multi-drugresistant tuberculosis cases (Chatterjee et al. 2018). Other infectious diseases, like HIV, malaria and lower respiratory infections are also major problems in India.

At the same time, the growing urbanization in India, changing lifestyles and rising income within a section of its population have also witnessed sharp increases in noncommunicable diseases, which account for $63 \%$ of all deaths in the country (World Health Organization 2018). For example, with an estimated 77 million diabetics (World Health Organization 2018), one in six people with diabetes in the world are from India. While currently more prevalent among higher-income states of India, the spread of diabetes to economically deprived sections of society is also becoming a matter of serious concern (International Diabetes Federation 2019). Over the last few decades, there has been a steady increase in the incidence of non-communicable diseases, such as cardiovascular diseases, respiratory diseases and diabetes (Anjana et al. 2017).

Given this disease burden profile of both communicable and non-communicable diseases in India, it is critical for India to ensure steady supply of medicines needed to treat them, such as rifampicin for tuberculosis, metformin for diabetes, analgesics like paracetamol, and antibiotics such as penicillin, cephalosporins and macrolides (Arokiasamy 2018). However, over the last two decades, there has been growing dependence on China for APIs and intermediates used to manufacture these drugs, which can be disastrous from a public-health point of view. Other countries from where India imports its APIs include Singapore, USA, Italy, Hong Kong and South Korea.

The Standing National Committee on Medicines is tasked with identifying the most essential medicines which will cater to majority of the healthcare needs of the Indian population. The committee revises the National List of Essential Medicine (NLEM), 2015, which has a total of 376 medicines, including many for which the import dependency is very high. Some of these fall under the category of cardiovascular drugs, diabetes drugs, antibacterial, anti-inflammatory, anti-tuberculosis and anti-protozoal drugs. Managing the supply of APIs for these essential medicines required for high disease burden categories would be key to the health security of the nation (Figure 4).

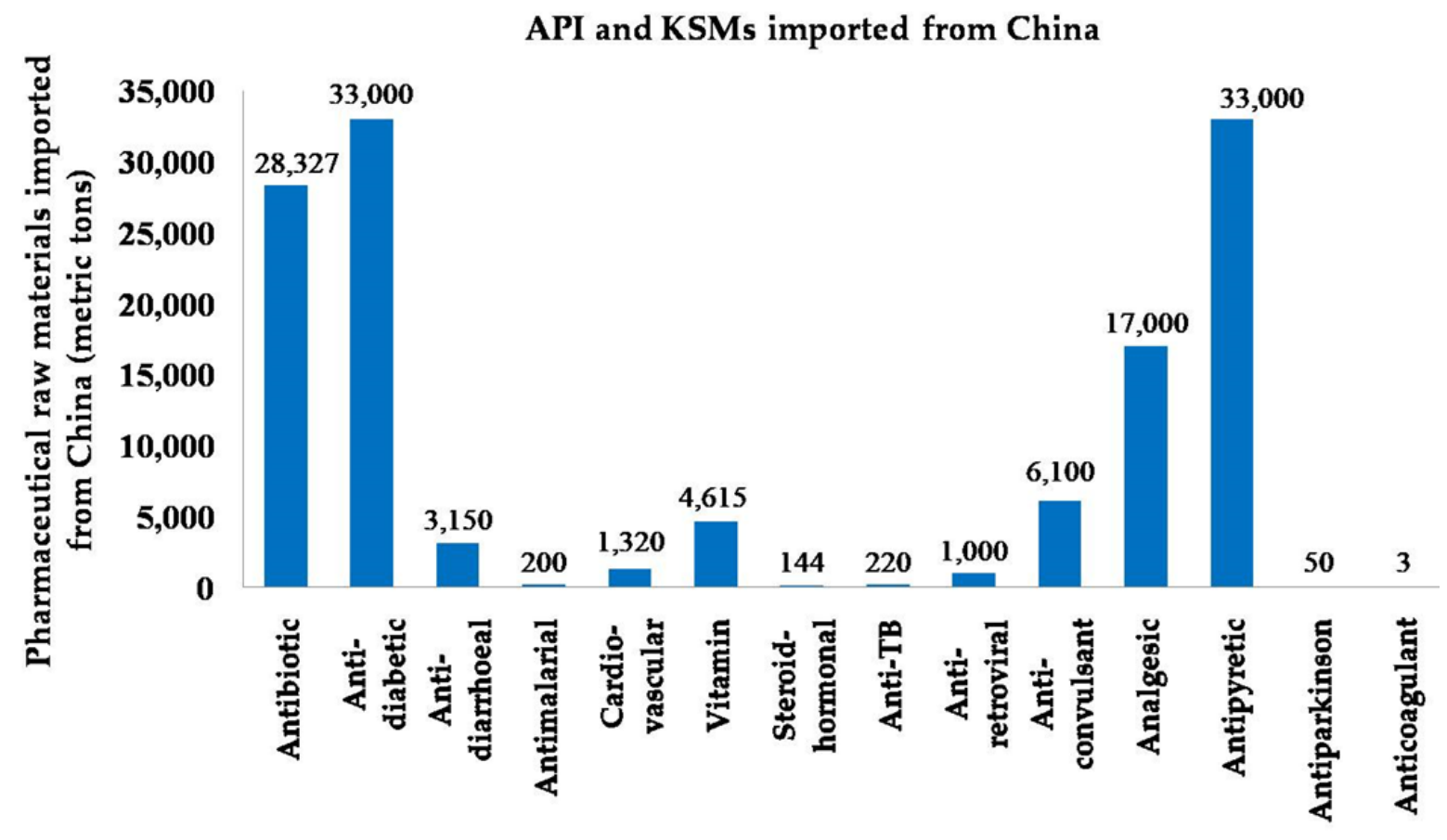

Figure 4. Pharmaceutical raw materials imported from China in terms of quantity (Export-Import Bank of India 2015). 
In some cases, including in the life-saving medicines category, the dependence on Chinese imports is as much as $80-100 \%$ (Figure 5). This is particularly more in the case of fermentation-based APIs, such as penicillin, erythromycin, etc., where it is almost $100 \%$ dependence on Chinese imports (Minister of Commerce and Industry, Department of Commerce, Government of India 2019). In recent years, there is also growing concern about the potential for shortages and stockouts of essential medicines, and escalation in prices due to supply uncertainties. Medicines shortages, whenever they occur and for whatever reason, put undue strain on healthcare professionals and endanger the life of patients in India.

For example, despite India having the most deaths caused by rheumatic heart disease in the world, with 111,000 fatal cases in 2015 (World Health Organization 2017b), the supply of antibiotic benzathine penicillin G (BPG), has reportedly been irregular in the country for the past 15 years (World Health Organization 2020; Al-Jazeera 2017). The commonly prescribed BPG is one the most effective medicine that can control rheumatic heart disease (Shah et al. 2013). In 2018, the Indian pharmaceutical industry faced an unprecedented shortage of vitamin $C$ tablets when many factories in China were shut due to stricter implementation of environmental norms (Thacker 2018). Sodium ascorbate, an ingredient used for making vitamin $\mathrm{C}$ tablets, mostly comes from China. Both of these are considered essential medicines as per NLEM. A committee constituted by the NPPA monitored possible supply chain disruptions of medicines in early 2020. It studied the variation in prices of 13 heavy import dependent APIs between 2019 and early 2020. The report states that, while most APIs did not have any significant change in price, the price of some APIs (such as enoxaparin) had almost doubled (Indian Drug Manufacturers' Association Bulletin 2020).

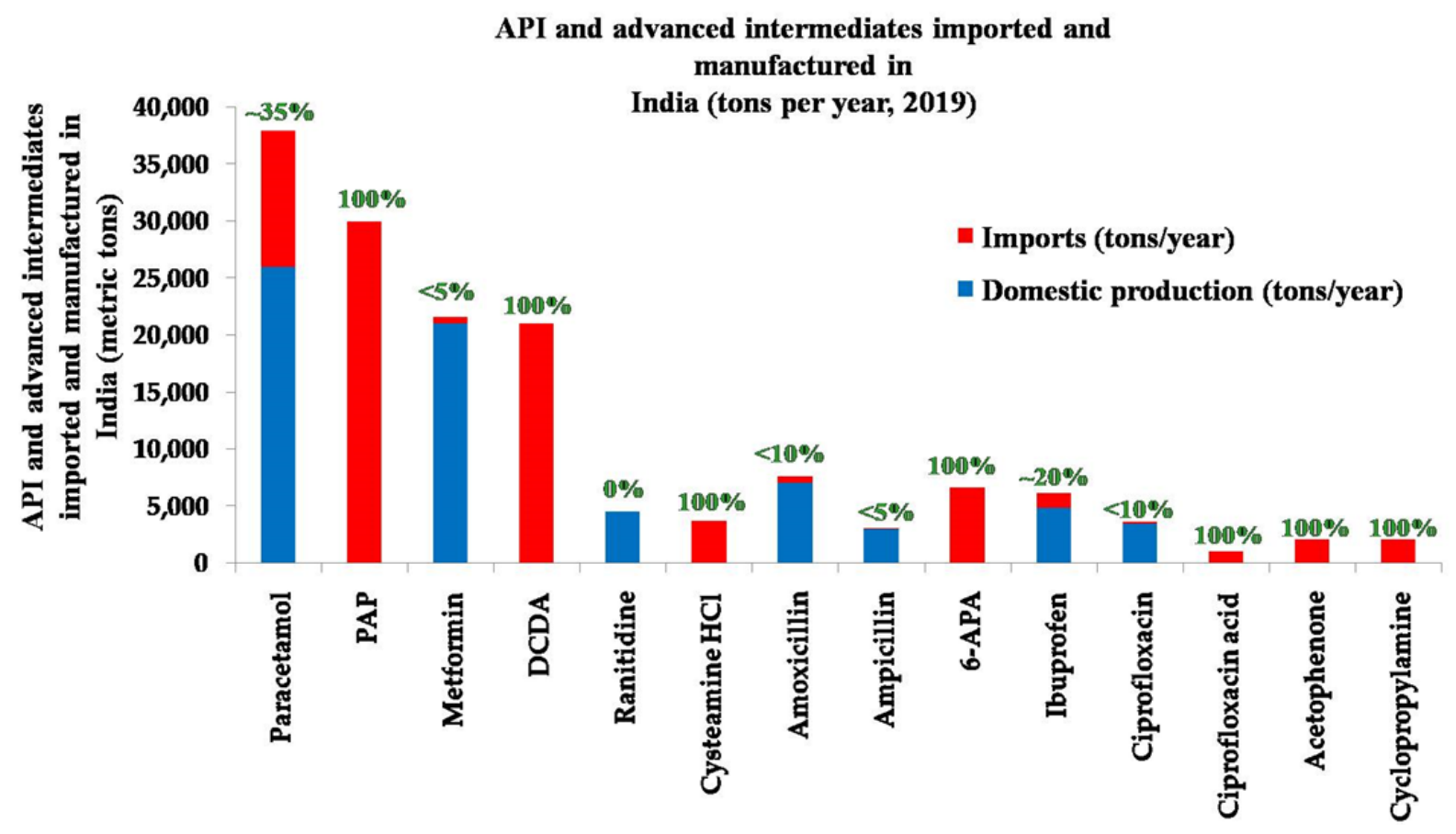

Figure 5. Indian imports of APIs and advanced intermediates highly dependent on China are shown. The numbers in green above each bar depicts the percentage of import dependence with respect to the total volume imported and manufactured (Ghosh 2019). 
With the heavy dependence on imports for ingredients and key starting material, the steady availability of many medicines on the NLEM was under threat recently. Many of these medicines rely on imports from very few sources. A committee set up to study the impact of the COVID-19 pandemic on pharma supply chains identified some of the medicines that were at risk of facing shortages. These medicines were of particular concern, since they relied heavily on manufacturing units based in Hubei province, which was under lockdown from mid-February 2020.

With support from various pharma-manufacturing associations, NPPA, merchant traders, the Directorate General of Foreign Trade (DGFT) and ICMR, a committee constituted by the DoP in February 2020, identified 58 medicines for which the dependence was very high. This list was further examined by an expert group constituted by ICMR in July 2020, and 29 of these were identified as essential and critical, for which no alternative medicine was suggested by the experts. Some of these medicines identified by the expert group included, amongst others, antibiotics such as azithromycin and metronidazole, vitamins such as vitamin B1 and vitamin C, and cardiovascular medicines such as atorvastatin and heparin. Through this exercise, the government now has a list of high-priority medicines, for which self-sufficiency in manufacturing or other means of securing access can be developed.

The global supply chain for medicines relies heavily on China for raw materials. There was international anxiety over disruptions in the pharma supply chain, especially during the initial few months when the epidemic hit. Hubei, a hub for pharmaceutical manufacturing, was under strict lockdown from mid-February, 2020. Even though India is a major pharma exporter, many experts were concerned about possible pharma supplychain disruptions, since India relies on Chinese raw material. Even in India, there were news reports of price escalation of certain medicines, and shortages seemed imminent (India TV 2020). These are critical from a health-security standpoint and could have heavy public health repercussions. The government took measures in response to the prevailing situation of the pandemic in India, including a ban on exports of certain medicines that it later lifted (Suneja and Chaudhary 2020).

The convergence of sources for pharmaceutical raw materials in a limited number of countries has been a matter of debate for a long time. However, there now seems to have developed a sense of urgency to encourage the near-shoring of pharma manufacturing. In the USA, where about $88 \%$ of API and $63 \%$ of formulation manufacturing are overseas (Drug Shortages 2019), the national regulator identified about 20 medicines that were at risk of shortages (USFDA Press Announcement 2020). Besides disruptions in their supply, drug shortages have also been attributed to the increased demand of certain medicines. There were similar news reports stating the risk of shortages of many medicines in Australia (The Guardian 2020). It has also forced the European Union to allocate 9.4 billion Euros towards a permanent reserve of essential medicines and urged the creation of non-profit pharmaceutical undertakings (Reuters 2020). Similar moves are also envisaged in the USA (US FDA 2020). Following the palpable threat of a major pharmaceutical supplychain disruption, it has now become evident that the global medical supply chains are not designed to withstand a pandemic. However, there are some solutions that may be considered (Figure 6). 
India's API dependence

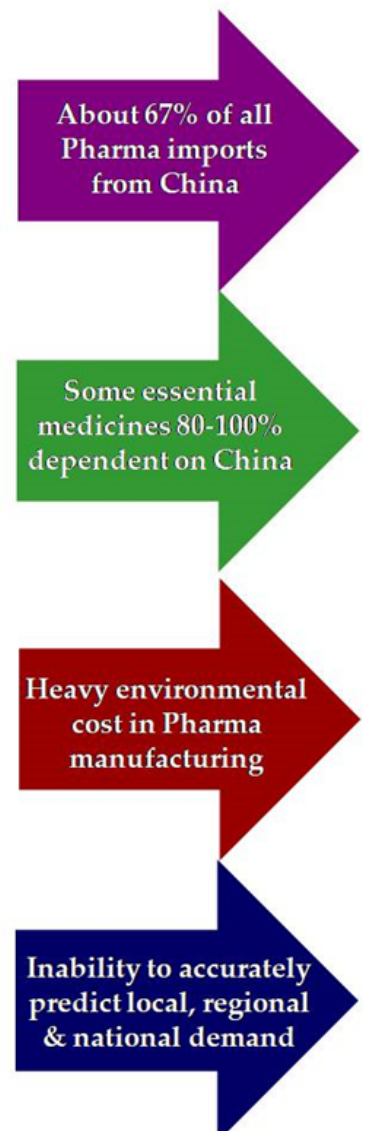

Possible solutions towards India's road to API independence

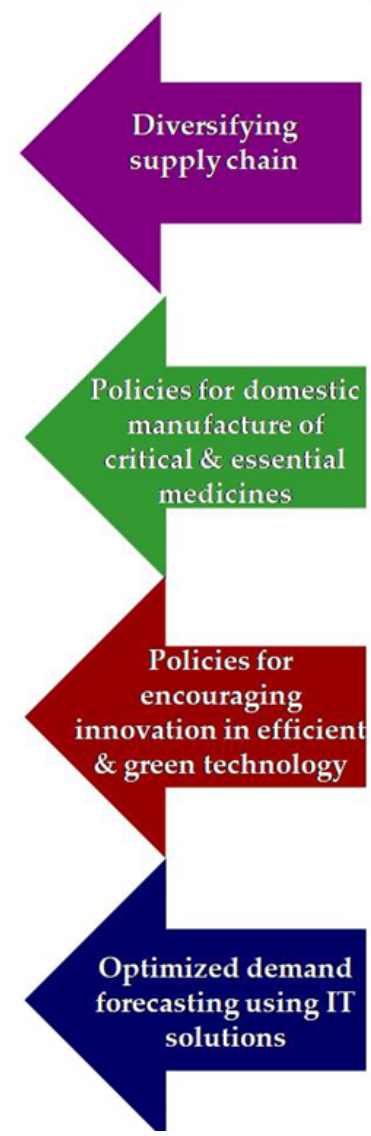

Figure 6. Some solutions proposed towards India's road to API independence.

\section{Current Understanding and Gaps in Information}

To overcome the problem of high dependence on import of API, intermediates and KSM, there needs to be a robust understanding of both the long-, mid- and short-term factors involved. This would involve gathering answers to certain critical questions:

- Why are there are no manufacturers that are ready to make these products in India?

- What are the main obstacles preventing pharma companies (an overwhelming majority of which are in the private sector) from ensuring national medicine security?

- What are the specific mid and long-term policy, investment and operational steps required to restart production of API for many essential medicines in the country?

- What can be done in the immediate run to prevent disruptions of both supply and prices of such essential medicines?

- How can new technological innovations incorporating green manufacturing, artificial intelligence and automation can increase efficiency, reduce environmental contamination and lower costs?

While currently there are many recommendations made by academia, industry and government committees for boosting domestic API manufacturing, many of them are long-term in nature and in some cases requiring substantial investments, too. What is needed to overcome any immediate shortages of medicines critically needed for public health purposes is more granular level information about different imported APIs and intermediates. For example, apart from identifying a list of essential medicines that are currently highly dependent on import of APIs, there is a need to put together all technical, policy-level and commercial options available to prevent disruptions in their supply and prices. 
For this purpose, detailed case studies of each essential medicine will need to be undertaken covering all aspects of production such as their imported ingredients, technology required, sourcing of raw materials, marketing of the finished product and collaborative business arrangements needed. This process will need to draw upon both existing information, some of it only available commercially, and a compilation of new data through concerted field work.

For each of the 58 molecules the DoP designated as highly dependent on imports (especially for the 29 molecules identified by ICMR as being critical and essential), detailed information needs to be compiled regarding their respective APIs, KSMs, intermediates, etc.; availability of stocks; domestic production capacity; commercial constraints involved in their production; and specific policy or financial incentives needed to restart their production or procurement from alternative sources. For example, to ensure availability of metronidazole, there should be an estimate of the current stock of metronidazole; availability or domestic manufacturing capacity of its API, KSM and intermediates; alternative sources for import; a determination of whether an export regulation is needed or not; incentives needed to increase domestic production, etc.

In the modern globalized economy, it is very difficult to establish any country as a utopian self-sufficient island. Some experts have suggested alternative strategies focused on reducing the risk of disruptions in the pharmaceutical raw material supply chain without necessarily resorting to increased domestic manufacturing. Some analysts and Indian private sector entrepreneurs, however, do not consider the Government's concerns on APIs as a key issue, pointing out that countries such as the USA and many European countries outsourced much of their API production because it is a relatively low margin business requiring substantial investments in environmental protection. According to them, India is merely following a path previously taken by many countries by outsourcing this low-margin business of commodified APIs to countries like China, Singapore and Hong Kong, while Indian manufacturers focus more on high-value APIs and on formulations (World Health Organization 2017b).

Some of the alternative strategies they suggest for ensuring an efficient supply of pharmaceutical raw materials are described below:

- Rather than being a hapless manufacturer of medicines which depends on imports for all its raw material requirements, India actually is a big exporter of bulk drugs itself (Orfonline 2017). Thus, the response to growing imports of API should be calibrated in a strategic manner and not be just reactive, based on immediate "threat" perceptions alone.

- $\quad$ A recent WHO study (World Health Organization 2017a) also states that, confronted with new regulatory and environmental restrictions, many Chinese pharma manufacturers are themselves considering moving their production activities overseas. Given this complex situation, analysts suggest that, along with encouragement of domestic manufacturing, India should also explore innovative options, to reduce dependence on a single country. For example, through technology transfer and assisting other countries in Asia or elsewhere, to develop API capacity, India can diversify the geography of API suppliers. This would have new challenges (e.g., employment opportunities for Indian scientists, essential goods diplomacy and foreign exchange over goods of strategic importance); however, it may be a way to undertake production in a more cost-competitive way.

- There is a need to monitor closely the trend in API import dependence to shape future policy, especially for medicines that are part of the Essential Medicines list, and developing new technology for cost-effective and non-polluting production of these medicines

- There is also need for compiling correct information regarding public sector manufacturing units and the feasibility of reviving them to boost national self-sufficiency in essential and critical medicines (Indian Council of Medical Research 2020a). 
- The government can channel revenue from import duties to support long-term risk diversification strategies, such as domestic manufacturing.

- India also needs to optimally work within the global trade regime framework in such a way as to benefit from the heavily subsidized international raw material supply (Orfonline 2017).

The Government of India sees the high level of dependence on imports of APIs and intermediates from any single country as a threat to national health security and to the future of the Indian pharma industry. Various committees/Task Forces have been appointed by Government of India, such as the Ministry of Health \& Family Welfare's Task Force on Formulating a Long Term Policy \& Strategy for Strengthening of Drugs Sector in the Country and the Ministry of Commerce \& Industry's Task Force on Proposed Policy for Promotion of Pharma Innovation and Exports. The Boston Consultancy Group, Confederation of Indian Industry and Drug Manufacturers' Association have made suggestions to strengthen the pharmaceutical sector with a focus on reducing the dependence for APIs, overall self-reliance in the sector and promotion of exports. These developments were summarizedby the Inter Ministerial Committee on APIs (Department of Pharmaceuticals, Ministry of Chemicals and Fertilisers. Government of India 2015). The recommendations of the Katoch committee were classified under four main categories:

(1) Infrastructure

- There is a need to establish mega parks for API or bulk drug manufacturing where basic infrastructure, such as land, water and electricity; common effluent treatment plants; captive power plants; and steam and testing facilities may be provided at a reasonable cost.

- To lower both financial and environmental costs, it should be mandatory to implement proper rules and regulations to arrest environmental contamination/pollution and achieve high-quality output.

- Advanced testing lab infrastructure should be created, to facilitate easier foreign trade.

(2) Financing

- At the earliest, set up two fully financed API clusters, one focused on fermentation and the other focused on producing APIs, using other technologies, while other clusters could be set up in five or six states, at a later stage. Some of these clusters may adopt state-of-the-art systems to function as model units.

- Dedicated equity funds for the development of these clusters could be provided by the government. Cluster developers and cluster participants could be provided tax-free status for 15 years.

- Provisions for incentives can be made for manufacturers, allowing them to set up large plants and import technology, reducing the cost of production.

(3) Regulatory approvals

- Ensure single-window clearance to manufacturers and make other support facilities easily available to them.

- The revival of public sector units (PSUs) for manufacturing selected and essential drugs (e.g., penicillin and paracetamol) and vaccines should be considered.

(4) Awards/recognitions

- Promotion of innovative ideas and products, awards to scientists for contributions made to the industry and patent protection of innovations could be undertaken to prompt further growth in the sector. 
Another task force, headed by Mr. Mansukh L. Mandaviya, Union Minister of State for Chemical and Fertilizers, was constituted in 2018 by the government, to provide a roadmap for India's API sector with implementable recommendations (Department of Pharmaceuticals, Ministry of Chemicals and Fertilisers. Government of India 2018). Industry bodies have also produced reports of their own and made several recommendations for supporting indigenous manufacture of APIs (Confederation of Indian Industry 2017). Some of their suggestions include the following:

- Ease the approval process and increase competitiveness to revive bulk drug manufacturing in India.

- Utilize existing capacities, focus on quality, identify critical APIs and secure the supply chain.

- Nurture entrepreneurship in the bulk drug industry with a conducive ecosystem of policies, regulations and financial incentives.

- Declare API as a strategic sector, encourage reverse brain drain and capacity creation.

- Achieve cost competence and self-sufficiency; India needs robust cluster development with a sustainable design.

Despite various efforts, the trend of high dependence on imports continues, as it seems to be linked to long-term structural issues, including profitability (of making certain kinds of API or intermediates in India), global market conditions and decline in Indian public-sector research and manufacturing (Table 2) (Abrol et al. 2018).

Table 2. Status of Indian public-sector drug manufacturers (Assocham India Indian API Market Outlook 2022 2019) *.

\begin{tabular}{|c|c|c|c|c|c|}
\hline Manufacturing Unit & $\begin{array}{c}\text { Hindustan } \\
\text { Antibiotics Limited }\end{array}$ & $\begin{array}{l}\text { Indian Drugs and } \\
\text { Pharmaceuticals } \\
\text { Limited }\end{array}$ & $\begin{array}{l}\text { Rajasthan Drugs \& } \\
\text { Pharmaceuticals } \\
\text { Limited }\end{array}$ & $\begin{array}{l}\text { Bengal Chemicals \& } \\
\text { Pharmaceuticals } \\
\text { Limited }\end{array}$ & $\begin{array}{c}\text { Karnataka } \\
\text { Antibiotics \& } \\
\text { Pharmaceutical } \\
\text { Limited }\end{array}$ \\
\hline Established in & 1954 & 1961 & 1978 & 1980 & 1981 \\
\hline Classification & Sick & Sick & Incipient sick & Sick & Profit making \\
\hline Net Worth & -488.10 & -7147.23 & -24.65 & -184.60 & 127.81 \\
\hline Turn over & 15.12 & 84.22 & 36.53 & 88.19 & 326.90 \\
\hline No. of employees & 2000 (1997) & 11,000 (1992) & $191(2013)$ & 1467 (1992) & 712 (2017) \\
\hline Year of closure & 2016 & 2016 & 2016 & 2016 & $\begin{array}{c}\text { Closure under } \\
\text { Consideration (Press } \\
\text { Information Bureau. } \\
\text { Government of India } \\
\text { 2020a) }\end{array}$ \\
\hline
\end{tabular}

PIB: Press Information Bureau. * Adapted with permission from the author.

More recently, in the year 2020, the DoP took a number of proactive steps to promote self-reliance in manufacturing pharmaceutical raw materials. In order to encourage domestic manufacturing of bulk drugs, the DoP proposed two innovative schemes-one is a promotion of bulk drug parks scheme, and the other is a production-linked incentives scheme (Table 3). These schemes are advocated under the broader vision of Atmanirbhar Bharat (self-sufficient India) to handhold an economy that is amidst a pandemic. Besides ensuring that supply chains for raw materials of essential medicines are intact, these schemes are also expected to strengthen the pharmaceutical exports, as well as make medicines accessible and affordable to the Indian population. The schemes are indicative of the government's keen interest to re-establish India's position as a global pharma hub. 
Table 3. Incentives for domestic API production (Gowda SS 2020b; Press Information Bureau. Government of India 2020b).

In March 2020 the Union Cabinet, chaired by the prime minister, approved the following schemes to reduce manufacturing cost of bulk drugs in the country and dependency on other countries for bulk drugs:

\begin{tabular}{ll}
\hline A. Scheme for Promotion of Bulk Drug Parks. & B. Production Linked Incentive (PLI) Scheme \\
$\begin{array}{l}\text { Decision is to develop } 3 \text { mega bulk drug parks in India, in } \\
\text { partnership with States. }\end{array}$ & $\begin{array}{l}\text { Financial incentive will be given to eligible manufacturers of } \\
\text { identified } 53 \text { critical bulk drugs on their incremental sales over } \\
\text { the base year }(2019 / 2020) \text {, for a period of } 6 \text { years. }\end{array}$ \\
\hline $\begin{array}{l}\text { Government of India will give Grants-in-Aid to states with a } \\
\text { maximum limit of INR. } 1000 \text { crore per bulk drug park. }\end{array}$ & $\begin{array}{l}\text { Out of 53 identified bulk drugs, 26 are fermentation-based bulk } \\
\text { drugs, and 27 are chemical-synthesis-based bulk drugs. }\end{array}$ \\
\hline $\begin{array}{l}\text { Parks will have common facilities such as solvent recovery } \\
\text { plant, distillation plant, power and steam units, common } \\
\text { effluent treatment plant, etc. }\end{array}$ & $\begin{array}{l}\text { Rate of incentive will be 20\% (of incremental sales value) for } \\
\text { fermentation-based bulk drugs, and } 10 \% \text { for } \\
\text { chemical-synthesis-based bulk drugs. }\end{array}$ \\
\hline
\end{tabular}

A sum of Rs. 3000 crore has been approved for this scheme for the next 5 years.

A sum of Rs. 6940 crore has been approved for the next 8 years.

The Promotion of Bulk Drug Parks scheme will be implemented by State Implementing Agencies (SIA) to be set up by the respective State Governments, and the target is to set up 3 mega Bulk Drug Parks. The selection of states where these parks would be set up were decided to be done through a challenge mode. Due to the well-designed selection criteria for selection of states for the parks, the state governments have come out with various incentives for the bulk drug units set up in these parks, including very competitive rates for land lease, electricity, water and steam. The Production Linked Incentive Scheme will be implemented through a Project Management Agency (PMA), to be nominated by the Department of Pharmaceuticals. The Scheme will be applicable only for manufacturing of 53 identified critical bulk drugs (KSMs/Drug Intermediates and APIs).

\section{Conclusions}

This report was put together based on desktop research, supplemented with information obtained through expert group meetings (Indian Council of Medical Research 2020b), as well as a series of interviews and discussions with key stakeholders. The information thus gathered touched upon many issues related to overcoming India's high dependence on pharmaceutical imports. The experts suggested various steps that may be taken by different stakeholders. This included further steps for research institutes, such as ICMR, Department of Science and Technology (DST), Council of Scientific and Industrial Research (CSIR); academic bodies involved in pharmaceutical and industrial research; pharmaceutical manufacturers and their associations; and for various relevant government departments, including DoP, Central Drugs Standard Control Organisation (CDSCO), etc. The short, mid- and long-term recommendations listed here are based on these inputs and reflect a variety of perspectives on the subject. These recommendations have taken the present shape following the final consultation meeting organized by ICMR, with all relevant stakeholders, on 3 March 2020. Some of these suggestions, especially fiscal measures in form of PLI Scheme and an incentive scheme for setting up Bulk Drug Parks by the states, have already been implemented by the government (Table 3), under the prime minister's vision for Atmanirbhar Bharat (self-sufficient India).

An organization, Pharma Bureau, has also been set up within DOP, to facilitate investment for ensuring faster statutory approvals from the central, state and local authorities, especially to facilitate environment clearances. Many initiatives have been taken by DoP, with the Ministry of Environment and Forest, as well as the Central Pollution Control Board, to facilitate timely approval with regard to API manufacturing in India. Moreover a new PLI Scheme to incentivize complex generics and complex APIs, among other products, was approved by the government recently.

Short-Term Measures

(1) Assessment of viability of indigenous manufacturing through government funding for the high-import-dependent 58 medicines (especially the most critical 29) may be estimated. Identify Indian pharmaceutical companies willing to manufacture these essential medicines or API, intermediates. 
(2) Policy interventions to revive brown field pharma units can lead to quick results, since many existing units have spare capacity or are in a position to increase production/diversify with minor additions to the existing plant. This can lead to the immediate availability of some of the critical APIs.

(3) Develop indicators to monitor the progress so that different stakeholders can be held accountable and progress can be measured objectively.

(4) Improve transparency of rules and speed of payment at both central and state level medicine procurement systems.

Mid- and Long-term Measures

- $\quad$ Policy measures

(1) Set up a National Mission to Secure Access to Essential Medicines, bringing various Ministries, government agencies and other key stakeholders together, to achieve time-bound goals for self-reliance by 2022, the 75th year of Indian Independence.

(2) Appropriately modify regulations and procedures to make medicine production more efficient and encourage value-based partnerships between all stakeholders.

(3) Set up model production facilities that are technology intensive and in the public sector or in partnership with private sector. Vertical integration needs to be encouraged with common logistics and facilities such as pharmaceutical Special Economic Zones may be contemplated as a policy measure.

(4) Diversify supply chain out of any country that tends to monopolize. Actively build supply networks in other countries around the world. Encourage and support Indian companies to become Indian MNCs with supply and manufacturing at many different locations.

(5) Carry out global health diplomacy required to expand access to global markets for essential medicines produced by Indian manufacturers, especially in countries of the Global South.

- $\quad$ Fiscal measures

(1) Promote the setting up of vertically integrated manufacturing facilities for essential drugs, at a competitive scale. The government can help set up capacities for these APIs/intermediates by providing fiscal incentives such as subsidized debt, tax and duty breaks on capital equipment. The government has already launched two schemes together valued at almost 10,000 crores, to promote domestic manufacturing (Table 3).

(2) Find ways to control imports of API and intermediates without violating WTO agreements especially when connected to national health security.

(3) API industry may be declared an infrastructure industry to facilitate availability of low cost credit.

(4) The Indian government may consider having the cost of utilities comparable to that of other countries that have attained self-sufficiency in pharmaceutical manufacturing. This can be achieved through various schemes such as investments in captive power plants, generation of steam as a by-product of electricity and common effluent management system.

- Technology measures

(1) CSIR and various other public sector labs have most of the technologies required in this endeavor. ICMR can assist CSIR labs prioritize their work by identifying which molecules are most essential/critical from a public health perspective. More efficient processes of synthesis, such as continuous manufacturing technologies and improved microbial strains for increased efficiency in fermentation-based products, should be incentivized.

(2) Develop a system to collect real-time data on medicine sales that will aid better demand forecasting and in deciding volumes of production. Consider appro- 
priate innovations in procurement of medicines within states to streamline the tendering process, thereby ensuring greater access to medicines nationally by implementing Universal Health Care, giving manufacturers a secure domestic market.

(3) Focus on innovative technologies and business models, e.g., Use of Internetof-Things, Big Data and Artificial Intelligence, for audit and data integrity, to ensure data-driven process control, optimization and continuous monitoring.

Author Contributions: B.B. conceived the idea, structured and approved the draft. P.D.V., S.S. (Shubhra Singh) and S.E.R. gave significant constructive inputs to the manuscript. J.J.C., P.D. and M.R. did extensive survey of the literature, analysis and wrote the paper. Y.K.G., V.M.K., V.K., S.S. (Sakthivel Selvaraj), R.R.G., A.K.D. and S.S. (Swarup Sarkar) provided data, critical reviews of the manuscript and guided the analysis. The opinion expressed in the paper are that of the authors' and do not represent views of their respective organizations or of any government. All authors have read and agreed to the published version of the manuscript.

Funding: Funding received from Indian Council of Medical Research, V. Ramalingaswamy Bhawan, Ansari Nagar, New Delhi-110077, India. The funding body was instrumental in providing support for organizing the various consultation meetings.

Data Availability Statement: The study does not report any data.

Acknowledgments: ICMR acknowledges the contributions of various ministries and government officials, including but not restricted to National Institution for Transforming India (NITI) Aayog, Department of Pharmaceuticals, Drug Regulations Section of Ministry of Health and Family Welfare, National Pharmaceutical Pricing Authority and Central Drugs Standard Control Organisation (CDSCO). Industry associations that have partnered with us in this consultation include Federation of Indian Chambers of Commerce and Industry (FICCI), Confederation of Indian Industry (CII), Indian Drug Manufacturers' Association (IDMA), Bulk Drug Manufacturers Association (BDMA), Organisation of Pharmaceutical Producers of India (OPPI). MSF Access Campaign India was consulted in the role of civil society organization. Various individual pharmaceutical manufacturers also provided their valuable industry insights. Mr. Satya Sivaraman, Medical Writer, Translational Global Health Policy Research Cell (TGHRC), Indian Council of Medical Research (ICMR), New Delhi, India provided overall research support and to collate all the information. Policy analysts and academicians who provided technical or editorial support included Dr Denis Broun (former) UNITAID, Geneva, Switzerland, Prof. Dinesh Kumar Abrol and Dr. Reji K. Joseph, Institute for Studies in Industrial Development, New Delhi, India, and Prof. Sudip Chaudhuri, Centre for Development Studies, Thiruvananthapuram, India.

Conflicts of Interest: The authors declare that they have no competing interests.

\section{References}

Abrol, Dinesh Kumar, Rollins John, and Amitava Guha. 2018. Economic Reforms and Pharmaceutical Manufacturing in India. New Delhi: Institute for Studies in Industrial Development, ISBN 978-81-938075-2-1.

Al-Jazeera. 2017. Why Is the World Suffering from a Penicillin Shortage? Available online: https:/ /www.aljazeera.com/indepth/ features /2017/05/world-suffering-penicillin-shortage-170517075902840.html (accessed on 19 March 2020).

Anjana, Ranjit Mohan, Mohan Deepa, Rajendra Pradeepa, Jagadish Mahanta, Kanwar Narain, Hiranya Kumar Das, Prabha Adhikari, PaturiVishnupriya Rao, BanshiSaboo, Ajay Kumar, and et al. 2017. Prevalence of diabetes and prediabetes in 15 states of India: results from the ICMR-INDIAB population-based cross-sectional study. The Lancet Diabetes \& Endocrinology 5: 585-96.

Arokiasamy, Perianayagam. 2018. India's escalating burden of non-communicable diseases. The Lancet Global Health 6: e1262-3. [CrossRef]

Assocham India Indian API Market Outlook 2022. 2019. Available online: https:/ / www.assocham.org/publications.php (accessed on 23 September 2019).

Chatterjee, Soumya, Husain Poonawala, and Yogesh Jain. 2018. Drug-resistant tuberculosis: Is India ready for the challenge? BMJ Global Health 3: e000971. [CrossRef] [PubMed]

Confederation of Indian Industry. 2017. Indian Bulk Drugs Industry-Regaining the Lost Glory. Available online: http:/ / ciipharma. in/pdf/API\%20final\%20report.pdf (accessed on 9 August 2020).

Department of Pharmaceuticals, Ministry of Chemicals and Fertilisers. Government of India. 2015. Salient Features of the Recommendations of the Katoch Committee Reporton APIs. Available online: https://pharmaceuticals.gov.in/sites/default/files/Katoch\% 20Committe\%20Report_0.pdf (accessed on 12 October 2020). 
Department of Pharmaceuticals, Ministry of Chemicals and Fertilisers. Government of India. 2018. Constitution of Taskforce on API. Available online: https://pharmaceuticals.gov.in/sites/default/files/Task\%20Force.pdf (accessed on 23 April 2020).

Dey, Sushmi, and Khomba Singh. 2009. Pharma Industry against Safeguard Duty on Chinese Antibiotics. Available online: https: / / economictimes.indiatimes.com/industry/healthcare/biotech/pharmaceuticals/pharma-industry-against-safeguard-dutyon-chinese-antibiotics / articleshow / 4382645.cms?utm_source=contentofinterest\&utm_medium=text\&utm_campaign=cppst (accessed on 9 August 2020).

Down to Earth. 2020. COVID-19 Exposes India's Dependence on China for Active Pharma Ingredients. Available online: https:/ /www. downtoearth.org.in/news/economy/covid-19-exposes-india-s-dependence-on-china-for-active-pharma-ingredients-70272 (accessed on 24 April 2020).

Drug Shortages. 2019. Root Causes and Potential Solutions. 2019 USFDAUpdatedon 2/21/20. Available online: https: / www.fda. gov/media/131130/download (accessed on 13 June 2020).

Export-Import Bank of India. 2015. Study on Indian Pharmaceutical Industry. Occasional Paper No. 37. Available online: https: //www.eximbankindia.in/Assets/Dynamic/PDF/Publication-Resources/ResearchPapers/39file.pdf (accessed on 23 April 2020).

Export-Import Bank of India. 2016. Indian Pharmaceutical Industry: Challenges and Prospects. Available online: https://www. eximbankindia.in/Assets/Dynamic/PDF/Publication-Resources/ResearchPapers/55file.pdf (accessed on 23 April 2020).

Ghosh, Prasanta Kumar. 2019. Government's Policiesand Growth of Pharmaceutical Industryin India 1947-2018: A Review. Discussion Paper\#236. Research and Information System for Developing Countries. Available online: http://ris.org.in/sites/default/files/ Publication\%20File/DP\%20236\%20P\%20K\%20Ghosh\%20DP-min.pdf (accessed on 24 April 2020).

Global Burden of Disease Report. 2017. Available online: https:/ /www.cseindia.org/2017-global-burden-of-disease-gbd-report-saysindia-has-the-second-highest-number-of-early-deaths-due-to-pm25-in-the-world----nearly-equals-china-6796 (accessed on 14 March 2020).

Gowda SS. 2020a. Launches Schemes and Announces Guidelines Paving Way for Setting Up of Bulk Drugs Parks \& Medical Devices Parks in the Country. Press Information Bureau. Government of India. Available online: https:// pib.gov.in/PressReleasePage. aspx?PRID=1641517 (accessed on 3 August 2020).

Gowda SS. 2020b. Import of Bulk Drugs/APIs. Press Information Bureau. Government of India. Available online: https:/ / pib.gov.in/ PressReleasePage.aspx?PRID=1606725 (accessed on 29 September 2020).

India TV. 2020. India Could See Shortage of Medicine as Coronavirus Hits Asia's Largest Pharmaceutical hub: India TV News. Available online: https:/ / www.indiatvnews.com/news/india/india-could-see-shortage-of-medicines-as-coronavirus-hits-asias-largest-pharmaceutical-hub-609425 (accessed on 13 June 2020).

Indian Council of Medical Research. 2020a. Minutes of Meeting for Discussion on Finalising White Paper Titled 'Securing Access to Essential Medicines'; New Delhi: Indian Council of Medical Research.

Indian Council of Medical Research. 2020b. Minutes of Meeting for Discussion on Finalising Manuscript Titled 'Essential Medicines and India's road to API Independence'; NewDelhi: Indian Council of Medical Research.

Indian Drug Manufacturers' Association Bulletin. 2020. Indian APIs \& Formulations for Global Healthcare. vol. 51. Available online: https:/ / www.idma-assn.org/pdf/idma-bulletin-21-april-2020.pdf (accessed on 23 April 2020).

Indian Pharmaceutical Alliance. 2019. Indian Pharmaceutical Industry-The Way Forward. Occasional Paper No. 176. Available online: https:/ / www.ipa-india.org/static-files/pdf/publications/position-papers/2019/ipa-way-forward.pdf (accessed on 10 October 2019).

International Diabetes Federation. 2019. Idf Diabetes Atlas, 9th ed. Available online: https://www.diabetesatlas.org/upload/ resources/material/20200302_133351_IDFATLAS9e-final-web.pdf (accessed on 14 March 2020).

Knowledge Partnership Programme. 2015. Promoting Active Pharmaceutical Ingredients Manufacturing in India. Available online: http:/ / www.ipekpp.com/admin/upload_files/Knowledge_2_39_Promoting_1936160980.pdf (accessed on 23 April 2020).

Market Wrap ICICI. 2019. Securities. Available online: http:/ / content.icicidirect.com/mailimages/ChineseAPI.html (accessed on 23 April 2020).

Minister of Commerce and Industry, Department of Commerce, Government of India. 2019. Report of the High-Level Advisory Group. Available online: https:/ / qcin.org/PDF/HLAG\%20Report\%20(Flyers\%20Included)_Oct\%2025,\%202019.pdf (accessed on 23 April 2020).

Orfonline. 2017. China as India's Main Bulk Drugs Supplier: Helplessness or Cautious Evolution? Observer Research Foundation: August 2017. Available online: https:/ / www.orfonline.org/expert-speak/china-india-bulk-drugs-supplier-helplessness-cautiousevolution/ (accessed on 12 August 2020).

Press Information Bureau. Government of India. 2020a. Cabinet Approves Extension/Renewal of the Extant Pharmaceuticals Purchase Policy (PPP) with the Same Terms and Conditions While Adding one Additional Product Namely, Alcoholic Hand Disinfectant (AHD) to the Existing List of 103 Medicines till Thefinal Closure/Strategic Disinvestment of the Pharma CPSUs. November 20. Available online: https:/ / pib.gov.in/PressReleaseIframePage.aspx?PRID=1592572 (accessed on 3 August 2020).

Press Information Bureau. Government of India. 2020b. Cabinet Approves Promotion of Domestic Manufacturing of Critical Key Starting Materials/Drug Intermediates and Active Pharmaceutical Ingredients in the Country. March 21. Available online: https:/ / pib.gov.in/PressReleasePage.aspx?PRID=1607483 (accessed on 25 April 2020). 
Reuters. 2020. EU Plans Permanent Stockpile of Essential Drugs, Medical Gear. May 8. Available online: https://in.reuters.com/article/ us-health-coronavirus-eu-medicines / eu-plans-permanent-stockpile-of-essential-drugs-medical-gear-idINKBN23421I (accessed on 13 June 2020).

Shah, Bela, Meenakshi Sharma, Rajesh Kumar, K. N. Brahmadathan, Vinod Joseph Abraham, and Rajan Tandon. 2013. Rheumatic Heart Disease: Progress and Challenges in India. The Indian Journal of Pediatrics 80: 77-86. [CrossRef] [PubMed]

SRS Bulletin. 2019. Sample Registration System Bulletin. Office of the Registrar General: 52, 1. Available online: https:/ censusindia. gov.in/vital_statistics/SRS_Bulletins/SRS_Bulletin-Rate-2017-_May_2019.pdf (accessed on 9 August 2020).

Suneja, Kritika, and Dipanjan Roy Chaudhary. 2020. COVID-19: SAARC Nations among 30 Asking India to Remove Export Ban on Key Drug. Available online: https:/ / economictimes.indiatimes.com/news/international/world-news/covid-19-27saarc-nationsamong-30-asking-india-to-remove-export-ban-on-key-drug/articleshow /75016370.cms?utm_source=contentofinterest\&utm_ medium=text\&utm_campaign=cppst (accessed on 13 June 2020).

Thacker, Teena. 2018. Vitamin C, Other Drugs in Short Supply as China Shutters Plants. Available online: https://www.livemint.com/ Industry/QJjkzYvQ30tksxWPFIIFpJ/Vitamin-C-other-drugs-in-short-supply-as-China-shutters-pla.html (accessed on 23 April 2020).

The Guardian. 2020. 'Massive Shortages': Rural Australian Pharmacies Low on Essential Medications Amid Coronavirus: The Guardian. Available online: https:/ /www.theguardian.com/world/2020/mar/12/massive-shortages-rural-pharmacies-lowon-essential-medications-amid-coronavirus-crisis (accessed on 13 June 2020).

US FDA. 2020. The US FDA Executive Order 13944 List of Essential Medicines, Medical Counter measures, and Critical Inputs (30 October 2020). Available online: https:/ / www.fda.gov/about-fda/reports/executive-order-13944-list-essential-medicinesmedical-countermeasures-and-critical-inputs (accessed on 12 August 2020).

USFDA Press Announcement. 2020. Available online: https://www.fda.gov/news-events/press-announcements/coronavirus-covid19-supply-chain-update (accessed on 12 June 2020).

World Health Organization. 2017a. China Policies to Promote Local Production of Pharmaceutical Products and Protect Public Health. Geneva: World Health Organisation. Available online: https:/ / www.who.int/phi/publications/2081China020517.pdf (accessed on 9 August 2020).

World Health Organization. 2017b. Indian Policies to Promote Local Production of Pharmaceutical Products and Protect Public Health. Available online: https:/ /www.who.int/phi/publications/2081India020517.pdf?ua=1 (accessed on 23 April 2020).

World Health Organization. 2018. Non-Communicable Diseases (NCD) Country Profiles. Available online: https://www.who.int/ nmh/countries/ind_en.pdf (accessed on 14 March 2020).

World Health Organization. 2020. Global Health Estimates. Available online: https://www.who.int/healthinfo/global_burden_ disease/en/ (accessed on 15 March 2020).

World Health Organization-Global Health Observatory. 2020. Life Expectancy Data by Country. Available online: http:/ /apps.who. int/gho/data/node.imr.WHOSIS_000001?lang=en (accessed on 21 April 2020).

World Health Organization-Global Tuberculosis Report. 2019. Available online: https:/ / www.who.int/tb/global-report-2019 (accessed on 9 August 2020). 